\title{
"Daño del engaño" en documentos privados. Aproximación al perjuicio en la falsificación de instrumentos privados
}

\author{
Nibil est aliud falsitas nisi veritatis imitatio \\ "La falsedad no es más que la imitación de la verdad" \\ (Justiniano)
}

\author{
Tatiana Vargas Pinto*
}

\begin{abstract}
RESUMEN
La tradicional interpretación de la falsificación de instrumento privado como una forma especial de estafa se basa principalmente en el daño patrimonial con que se define el "perjuicio de tercero" que exige. Esta opción se cuestiona no sólo frente a la necesidad de que exista este delito de falsificación ante las amplias formas de engaño del delito de estafa, sino también respecto de la noción de falsedad y del perjuicio que requiere. En este sentido, se pone especial énfasis en la lesividad de la conducta de falsedad y la afectación que supone tal perjuicio.
\end{abstract}

Falsificación - instrumento privado - perjuicio.

\section{"Damage of Deception" in private documents. Approaching the damages on falsification of private instruments}

\begin{abstract}
The traditional interpretation of private instrument's forgery as a special form of fraud is based mainly on the pecuniary damage required to define the damage or harm to a third party. Not only is this option questioned in light of the need that this crime of forgery may exist facing the wide forms of deceit of fraud, but also in reference to the idea of falseness and the type of damage it requires. In this sense we place special emphasis on the harmfulness of falseness conduct and the affectation which given damage implies.
\end{abstract}

$$
\text { Forgery - private instrument - damage }
$$

* Abogada, Doctora en Derecho, Profesora de Derecho Penal, Universidad de los Andes, San Carlos de Apoquindo 2200, Santiago de Chile. Trabajo realizado en el marco del Proyecto Fondecyt de Iniciación No11100126, tatianavp@uandes.cl

Artículo recibido el 30 de agosto de 2011 y aceptado para su publicación por el Comité Editorial el 28 de octubre de 2011. 


\section{Presentación Del problema}

$\mathrm{E}$ 1 delito de falsificación de instrumentos privados no suele llamar mucho la atención. ¿Por qué? Si, por ejemplo, Pedro firma un cheque de otra persona como si fuera ésta y lo presenta en una tienda donde compra varios artículos electrodomésticos, hay un perjuicio para el establecimiento comercial por la falsedad. La conducta se considera una forma especial de estafa por el particular engaño y se prefiere el delito de falsificación, en general, precisamente por el principio de especialidad. El perjuicio que agrega este tipo de falsificación frente al de documentos públicos ${ }^{1}$ parece ser el elemento que lo une a la estafa. Esta comprensible reconducción no es tan clara ante nuevas formas de falsedad y de instrumentos, como la "clonación" de tarjetas de crédito que no exige perjuicio para su sanción (art. 5 de la Ley $\left.\mathrm{N}^{\circ} 20.009\right)^{2}$. La falsificación de tarjetas de crédito o débito que se castiga desde 2005 y surge de una moción parlamentaria de noviembre de 2002 para limitar la responsabilidad de los usuarios por hurtos y robos de tarjetas de crédito que se amplía para casos de falsedad ${ }^{3}$. Antes, ese mismo año, en el mes de septiembre, el Ejecutivo presentó un proyecto de ley específico para sancionar la falsedad en cheques, tarjetas y otros documentos electrónicos, a propósito de los delitos informáticos. Se destaca porque el proyecto fue desarchivado en 2008 y está en segundo trámite constitucional, con modificaciones al Código Penal

${ }^{1}$ Art. 197 del C.P. que trata la falsificación de instrumentos privados con relación al art. 193 que sanciona la falsificación de documentos públicos o auténticos.

${ }^{2}$ Art. 5 de la Ley $\mathrm{N}^{\circ}$ 20.009: "Las siguientes conductas constituyen delito de uso fraudulento de tarjeta de crédito o débito:

a) Falsificar tarjetas de crédito o débito.

b) Usar, vender, exportar, importar o distribuir tarjetas de crédito o débito falsificadas o sustraídas.

c) Negociar, en cualquier forma, con tarjetas de crédito o débito falsificadas o sustraídas.

d) Usar, vender, exportar, importar o distribuir los datos o el número de una tarjeta de crédito o débito, haciendo posible que terceros realicen operaciones de compra o de acceso al crédito o al débito que corresponden exclusivamente al titular.

e) Negociar, en cualquier forma, con los datos o el número de la tarjeta de crédito o débito, para las operaciones señaladas en la letra anterior.

f) Usar maliciosamente una tarjeta bloqueada, en cualquiera de las formas señaladas en las letras precedentes.

La pena por este delito será de presidio menor en cualquiera de sus grados.

Esta pena se aplicará en su grado máximo, si la acción realizada produce perjuicio a terceros”.

${ }^{3}$ Así, en el Informe de la Comisión de Economía, el señor Enrique Sepúlveda Rodríguez afirma que: "el sistema propuesto no solamente debería alcanzar a los casos de pérdida de la posesión o tenencia material de la tarjeta, sino también a aquéllos en que el titular de la misma se entere, por cualquier medio, que un tercero ha hecho uso indebido de la tarjeta o se encuentre en condiciones de hacerlo, sin que el titular haya dejado de tenerla materialmente, tales como las situaciones de falsificación o clonación de tarjetas, o de captura de los datos, claves, números u otros antecedentes que permiten utilizarla”. Su sanción fue propuesta por el Senador Lavanderos en 2004 (Boletín N $\mathrm{N}^{\circ}$ 3129-03), que se precisó con las observaciones del profesor Waldo del Billar. 
y al DFL $N^{\circ} 3$ de 1997 (que contiene el texto refundido, sistematizado y concordado de la Ley General de Bancos).

El Mensaje del Ejecutivo de 25 de septiembre de 2002 (N. ${ }^{\circ}$ 13-348) fue claro respecto del problema que pretendía atacar con ocasión al desarrollo del comercio electrónico, que se extendió a otros documentos:

"En efecto, el desarrollo tecnológico también ha dado lugar al llamado comercio electrónico a través de Internet, caracterizado por transacciones no presenciales entre contratantes que por lo general no se conocen personalmente, muchas veces ubicados en lugares muy distantes. A pesar de sus bondades, uno de los principales obstáculos para el mayor desarrollo del comercio electrónico, es su déficit de seguridad y respaldo. [...]

Ahora bien, la consagración legal de los documentos electrónicos, de su validez y fuerza probatoria, permitiría interpretar que, en cuanto documentos, les son directamente aplicables las normas generales sobre falsedad documental sin necesidad de modificaciones legislativas; sin embargo, parece preferible zanjar cualquier duda sobre la incidencia de la normativa extrapenal en el ordenamiento punitivo, especialmente si se tienen en consideración las dudas ya existentes sobre el concepto convencional de documento".

El proyecto desarchivado además alude a documentos electrónicos que se consideran “documentos" desde la Ley N 19.799 de 12 de abril de $2002^{4}$. Podría pensarse que la iniciativa no tiene relevancia precisamente por eso: al estimarse documentos pasan automáticamente a los tipos de falsedad comunes del Código Penal. Ocurre que esta inclusión no es tan clara 5 . En el Mensaje citado refleja precisamente esta duda por la inseguridad que generaría una regulación extrapenal, la noción de documento y la importancia de la falsificación de otros "documentos plásticos", que no quedan comprendidos en las falsedades documentales tan fácilmente. Por eso optó por incorporar al Código Penal la falsedad de "tarjetas de crédito, débito o pago provistas de banda magnética u otro

${ }^{4}$ Art. 2 "Para los efectos de esta ley se entenderá por:

d) Documento electrónico: toda representación de un hecho, imagen o idea que sea creada, enviada, comunicada o recibida por medios electrónicos y almacenada de un modo idóneo para permitir su uso posterior". Esta redacción permite comprender la crítica de Garrido Montt, M., "El documento, en especial el público o auténtico, en el ámbito penal”, en Revista de Derecho, Pontificia Universidad Católica de Valparaíso, t. XXVI, 2005, pp. 199 y 200, a su condición de documento para el delito de falsificación y la existencia del citado proyecto de ley que busca sancionar especialmente tales falsedades.

${ }^{5}$ Por esta misma razón Hernández Basualto, H., "Uso indebido de tarjetas falsificadas o sustraídas y de sus claves", en Polit. crim., $\mathrm{N}^{\circ}$ 5, 2008, A2-5, p. 38, destaca la conveniencia de la sanción de la falsificación y del uso abusivo de tarjetas de crédito o débito por la Ley $\mathrm{N}^{\circ} 20.009$, aunque su definición como documento es menos segura que la de documentos electrónicos en general. 
dispositivo técnico de almacenamiento de datos" ${ }^{\text {. }}$. Luego, se modifica esta propuesta y se suma la reforma al DFL $\mathrm{N}^{\circ} 3$ (Boletín $\left.\mathrm{N}^{\circ} 3083-07\right)^{7}$.

De acuerdo con las anteriores anotaciones, ya no se necesitaría "perjuicio de tercero" en la falsificación de instrumentos privados con especial contenido patrimonial, al servir como medios de pago ${ }^{8}$. Su tratamiento se mantendría en los términos de la falsedad de documentos públicos. La propuesta sigue la línea no sólo de la clonación de tarjetas de crédito señalada, sino también de la falsificación de letras de cambio, el hacerlas circular o introducirlas maliciosamente en el territorio de la República, del art. 110 del DFL $\mathrm{N}^{\circ} 3^{9}$, que no exige perjuicio. El elemento que, en principio, separaría las falsificaciones de documentos públicos de las de instrumentos privados se cuestiona y, con ello, se pone en jaque la estructura del tipo de falsificación de instrumentos privados. ¿Tienen ambas falsedades la misma estructura? Todavía puede rechazarse para otros instrumentos privados (fuera del art. 5 de la Ley $\mathrm{N}^{\circ} 20.009$ y del art. 110 del DFL $\mathrm{N}^{\circ}$ 3), sobre todo si no son mercantiles, pues el art. 197 del Código Penal exige perjuicio de tercero. Aun así, el diputado señor Bustos ${ }^{10}$ sostuvo que la modificación altera el sistema de regulación de esta clase de falsedades, que obliga a reformar íntegramente su tipología penal. A ello se suma la poca claridad respecto de este delito. El actual art. 197 evidencia dificultades al definir la misma conducta típica que no han sido atendidas, como las formas de falsedad que se admiten por la técnica de remisión a los casos del art. $193^{11}$. Se cuestiona la configuración de este delito a partir del perjuicio que exige, pero su estudio demanda también el examen de los demás requisitos.

6 “2) Sustitúyese el inciso segundo del artículo 197 por los siguientes incisos:

'Si tales falsedades se hubieren cometido en letras de cambio u otra clase de documentos mercantiles, se castigará a los culpables con presidio menor en su grado máximo y multa de dieciséis a veinte unidades tributarias mensuales, o sólo con la primera de estas penas atendidas las circunstancias. Del mismo modo se castigará al que forjare o alterare tarjetas de crédito, débito o pago provistas de banda magnética u otro dispositivo técnico de almacenamiento de datos.

En las mismas penas de los incisos anteriores incurrirá respectivamente el que, con perjuicio de tercero, forjare o alterare un documento privado electrónico suscrito por medio de firma electrónica”.

7 3) Agrégase en el Decreto con Fuerza de Ley $N^{\circ} 3$, de 1997, del Ministerio de Hacienda, que fija el texto refundido, coordinado y sistematizado de la ley General de Bancos, el siguiente artículo 161, nuevo: 'Artículo 161. El que cometiere falsedad forjando cheques o tarjetas de crédito emitidos por entidades sometidas a la fiscalización de la Superintendencia de Bancos e Instituciones Financieras, será sancionado con pena de presidio menor en sus grados mínimo a medio y multa de once a quince unidades tributarias mensuales, salvo que por aplicación del artículo 197 del Código Penal le correspondiere mayor pena”".

${ }^{8}$ La extensión de medios que contempla puede llegar, como lo señaló el entonces Ministro de Justicia, señor Bates, a abarcar incluso los "modernos medios de pago para acceso a servicio de transporte y carreteras". Cámara de Diputados, Sesión 54a de 11 de marzo de 2003, Publicación Oficial Redacción de Sesiones, p. 29.

9 Art. 110 DFL $\mathrm{N}^{\circ}$ 3: "Los que falsificaren las letras de crédito, hicieren circular o introdujeren maliciosamente en el territorio de la República las letras falsificadas, serán castigados con las penas asignadas a los falsificadores de billetes del crédito público”.

${ }^{10}$ Informe de la Comisión de Constitución, Legislación y Justicia recaído en el Proyecto de Ley que Modifica el Código Penal con el Objeto de Recepcionar, en los Tipos Penales Tradicionales, Nuevas Formas Delictivas Surgidas a Partir del Desarrollo de la Informática, Boletín N. ${ }^{\circ}$ 3083-07.

${ }^{11}$ Art. 197 "El que, con perjuicio de tercero, cometiere en instrumento privado alguna de las falsedades designadas en el artículo $193 \ldots .$. 


\section{Conducta de FAlsedad y OBjeto FAlseado}

Con la omisión del elemento perjuicio para la falsificación de ciertos instrumentos mercantiles, el primer nexo con la estafa desaparece. Ahora, se mira la conducta de falsedad en sí misma. ¿En qué consiste? ¿Coincide con el engaño de la estafa? En la estafa la modalidad de engaño no parece preocupar, porque en general se considera un medio para afectar el patrimonio ajeno, un engaño patrimonial. Se identifica "defraudar" con "perjuicio patrimonial por engaño". Así, se desprende tanto del art. 468 del Código Penal, que habla de defraudar a otro mediante ciertos engaños, como del art. 473, que los considera derechamente sinónimos: "defraudare o perjudicare a otro" usando de engaño.

El perjuicio aparece como exigencia básica del delito de estafa. Su ausencia en las falsificaciones especiales presentadas permite cuestionar cuál es el daño ahora. Difícil será sostener una lesión patrimonial en los términos de la estafa, aunque la falsedad podría definirse como el engaño de la estafa. Habrá que ver en qué consiste la conducta de falsedad. Si ella interesa en instrumentos privados con un marcado contenido económico o comercial, ¿qué sucede con otros instrumentos privados? Para ellos se sigue aplicando el art. 197 del Código Penal que requiere perjuicio de tercero. Este elemento parece definirse igualmente en términos de lesión patrimonial, aunque la falsedad documental puede no referirse a un objeto con contenido patrimonial.

El delito que en esta exposición se presenta no se define sólo por el perjuicio que reclama, pues lo exige por la clase de conducta: la falsificación de un instrumento privado. El perjuicio no es necesario cuando se trata de falsificar documentos públicos. Algo hay en la conducta que vale la pena observar y el objeto es determinante. Destaca por ahora la preocupación de Cousiño ${ }^{12}$ por la idoneidad de la falsedad y la misma "potencia dañosa" del objeto material frente al perjuicio con un caso. Cita el ejemplo de quien forja un instrumento para afectar la honra de una persona y uno de sus familiares lo toma y sufre un ataque que le causa la muerte. Junto con ilustrar sobre la idoneidad de la conducta de falsedad, subraya el vínculo entre la clase de falsedad y la modalidad del perjuicio. Además, muestra un perjuicio distinto de la lesión patrimonial, la muerte de una persona (daño a la vida), y una conducta de falsedad que tendría una afectación propia, alcanzar la honra de una persona (daño a la honra). Conducta y perjuicio tendrían un alcance determinado y ambos estarían desvinculados. Es fundamental indagar sobre la clase de perjuicio, pero ante la conducta de falsedad. Por tal razón, veremos ahora en qué consiste ésta y sobre qué recae.

\section{Determinación de la falsedad}

La vinculación de la falsificación de instrumentos privados con la estafa no parece venir únicamente del perjuicio. La falsedad se comprende como una forma de engaño

${ }^{12}$ Cousiño Mac Iver, L., La falsificación de instrumento privado (ensayo de construcción jurídica del delito en Chile), Stanley, Santiago, 1944, pp. 29-31 y 41. 
particular. ¿Se trata de un "engaño patrimonial”? En el mismo caso expuesto por Cousiño se muestra de otra clase, aunque no se advierte mayormente. Quizá ese ejemplo (una carta con alusiones contra la honra de una persona leída por un familiar que fallece por ello) haga pensar que no es más que una injuria a la que no puede imputarse el resultado muerte del familiar. Podría aun cuestionarse la respuesta frete a una falsedad que no estaría considerada por el castigo de la injuria. Si, en cambio, tomamos nuestro ejemplo base, la falsificación de un cheque o un pagaré para comprar determinados productos, su referencia a la estafa parece lógica. Desde este caso -que además parece general-, ¿qué relevancia real tiene la existencia de este delito de falsificación cuando uno mira la amplitud de las formas de engaño en la estafa? Basta examinar los citados arts. 468 y 473: cualquier otro engaño semejante; cualquier engaño que no se halle expresado en los artículos anteriores.

La referencia al engaño de la estafa tiene sentido cuando se trata de un cheque, pagaré o cualquier otro instrumento mercantil por su particular contenido. Sin embargo, antes del objeto sobre el que recae la conducta, procede definir en qué consiste la conducta. El art. 197 habla de cometer falsedades y remite sus modalidades a las que señala el art. 193 para la falsificación de documentos públicos. Este genérico reenvío ya genera dudas respecto de las hipótesis que se aceptan, cuando la disposición atiende a una clase distinta de objeto (documento público o auténtico). De hecho, suelen rechazarse los supuestos de los $\mathrm{N}^{\mathrm{o}} \mathrm{s} 4,7$ y $8^{13}$.

Este último parece evidente pues alude a la ocultación en perjuicio del Estado o de un particular de cualquier "documento oficial". La naturaleza del objeto impide su aplicación. Sin embargo, no se comprende totalmente la exclusión del № 4 que alude a la falta de verdad en la narración de los hechos, cuando es posible imitar la verdad en el contenido de un instrumento privado. De hecho, se entendería más el rechazo de los $\mathrm{N}^{\circ}$ s 1 y 2 , el contrahacer o fingir letra, firma o rúbrica y el suponer la intervención de personas que no la han tenido, que pueden vincularse con exigencias oficiales de autenticación, aunque los términos de la ley tampoco suponen esta limitación. El $\mathrm{N}^{\circ} 7$ podría aceptarse en el sentido expuesto, porque alude a dar copia en forma fehaciente de un documento supuesto o manifestando algo distinto de lo que contenga el original ${ }^{14}$. Esta hipótesis exige solo que exista un documento original y no se restringe necesariamente a un documento público. Semejantes

${ }^{13}$ Ya desde Bañados Espinosa, F., Código Penal de la República de Chile concordado y comentado, Dirección de Impresiones L. A. Lagunas M., Santiago, 1920 p. 185.

${ }^{14}$ Esta exclusión podría estar motivada además por los comentarios de Pacheco, J. F., El Código Penal concordado y anotado, $5^{\text {a }}$ ed., Imprenta y Fundición de Manuel Tello, Madrid, 1881, t. II, p. 307, que rechaza este caso junto con el del número 8. Así, Vera, R., Código Penal de la República de Chile comentado, Imprenta de P. Cadot y Ca, Santiago, 1883, p. 379. La afirmación de Pacheco se basa en el "valor" de las copias. Entiende que solo existen copias con valor en actos ante notarios (escribanos). Esta idea puede cuestionarse justamente frente al efecto o fuerza que se atribuyen a las copias de otros documentos. ¿No tiene valor dar copia de un instrumento privado que no existe? Supondría su fabricación y si existe la falsedad de la copia no es realmente tal por el hecho de que solo haya un original y se "fabrica" una copia sin alcance alguno. No toda copia será 
ideas suponen negar toda mutación de verdad en el contenido de las declaraciones. En esta línea Etcheberry ${ }^{15}$ critica toda falsedad ideológica e incluso toda hipótesis de forjamiento de un documento. Así, extiende los supuestos improcedentes a los $\mathrm{N}^{\mathrm{o}} \mathrm{s} 2,3,4,7$ y 8 . Es decir, suma la suposición de personas que no han intervenido y la atribución de declaraciones o manifestaciones a quienes hubieren intervenido diferentes de las realizadas. No se comprende mucho la inclusión de este último supuesto y no la del $\mathrm{N}^{\circ} 1$ relativo a letras, firma y rúbrica. Funda su tesis en que el particular no está obligado a decir verdad. Ciertamente no tiene las funciones e injerencia de un funcionario público, pero es cuestionable que no existan obligaciones cuando se interactúa con otro, sobre todo en el tráfico jurídico ${ }^{16}$. Interesa claro cuando el objeto está destinado a producir efectos jurídicos, se utiliza. Estas afirmaciones de Etcheberry chocan incluso desde su noción amplia de documento, donde interesa cualquier objeto que alcance el tráfico jurídico ${ }^{17}$.

Según la clase de objeto (instrumento privado) falsificado, los términos de la ley parecen oponerse únicamente al supuesto de ocultamiento. Sin negar que la admisión de los otros casos depende del sentido de la norma que sanciona las falsificaciones de instrumentos privados ${ }^{18}$, la respuesta pasa por la definición del objeto. Además, las

realmente falsedad y su definición no debe estar ajena a los efectos de la copia y específicamente al fin de la norma que sanciona tales falsedades.

${ }^{15}$ Etcheberry, A., Derecho penal. Parte especial, $3^{\text {a }}$ ed., Editorial Jurídica de Chile, Santiago, 1998, t. IV, pp. 173 y 174. En este sentido también Garrido Montt, M., Derecho penal, parte especial, 4a ed., Editorial Jurídica de Chile, Santiago, 2008, t. IV pp. 63-65, 88. Sin embargo, sorprende este límite cuando conecta los supuestos de falsedad que la ley sanciona no con una obligación especial de decir verdad sino con el alcance de la norma. Afirma que la ley se limitó a prohibir ciertas adulteraciones "que ponen en peligro la confianza que las personas depositan en ciertos objetos marcados o signados por la autoridad como auténticos, o en aquellos que por la libre decisión de la voluntad de los particulares representan un acontecimiento o importan una obligación o interés”. Ibíd, p. 52. De hecho, en la jurisprudencia española se admite que a pesar de la derogación de uno de los supuestos que se consideran falsedad ideológica, su sistema no ha adoptado el modelo italiano que distingue expresamente entre falsedad ideológica y falsedad material, por ejemplo. SAP de Burgos, Sec. $1^{\text {a }}$ de 18 de marzo de 2003 (SP/AUTRJ/96941).

${ }^{16}$ De hecho, en el ámbito civil se habla con bastante soltura de las obligaciones en las "tratativas preliminares” y antes ya se admitía relevancia jurídica de la mera oferta. Ver en general, Barrientos Zamorano, M., Daños y deberes en las tratativas preliminares de un contrato, LegalPublishing, Santiago, 2008, passim; Zuloaga Ríos, I. M., Teoría de la responsabilidad precontractual. Aplicaciones en la formación del consentimiento en los contratos, LegalPublishing, $3^{\text {a }}$ ed., Santiago, 2008, passim. Ruiz Pulido, G., "Instrumento público y ley penal”, en Revista de Derecho, Consejo de Defensa del Estado, N 6, 2002, p. 80, cuestiona derechamente esta exclusión frente a la necesidad social y la "compleja red de intercambios" en cuanto ha obligado al legislador a cargar al particular con el deber de veracidad, por ejemplo, en obligaciones tributarias o aduaneras.

${ }^{17}$ Etcheberry, Derecho..., t. IV, p. 158, el mismo, "El objeto jurídico en los delitos de falsedad documental", en Revista de Ciencias Penales, 1961, t. XX, pp. 55-61; "El objeto material del delito de falsedad documental: documentos y sus clases”, en Revista de Ciencias Penales, 1961, t. XX, pp. 230-232.

18 Valdés Matus, O., De la falsificación de la letra de cambio, Memoria de Prueba para optar al Grado de Licenciado en Ciencias Jurídicas y Sociales de la Universidad de Chile, Editorial Universitaria, Santiago, 1960, p. 23, afirma que si se acepta la existencia de un mismo bien jurídico para falsedades de documentos públicos y de instrumentos privados no procede discriminar entre las distintas formas de falsificación documentaria. 
modalidades del art. 193 vienen a delimitar los casos de falsedad relevante, que exigen fijar su núcleo o esencia, en qué consiste una conducta de falsedad frente a la clase de objeto de que se trata.

\subsection{Noción de falsedad}

Nuestro legislador habla de cometer una "falsedad" cuando describe el comportamiento, pero también utiliza el término "falsificación” en los párrafos que contemplan los delitos. ¿Son diferentes? ¿A qué se refieren? Para descubrir su noción hay que ir a la fuente: además del sentido natural y etimológico de las palabras, su origen. En el plano común u ordinario, puede hacerse una primera distinción. Falsedad alude a la falta de verdad referida a personas o cosas, mientras que falsificación se refiere al comportamiento, a la acción. Puede ser útil la separación entre "objeto falso" y "conducta de falsificación” para la apreciación del juzgador, pero no parece hacer diferencia respecto de la concepción de ambos términos ${ }^{19}$. Empero, semejante disociación repercute en las formas de conductas, pues la falsificación, como acción y efecto de falsificar, requiere de un objeto que no necesitaría la falsedad, al identificarse con lo falso. Ésta pasaría a ser el género que comprendería tanto la creación total (sin objeto) como parcial de algo ${ }^{20}$.

A pesar de la distinción, falsedad y falsificación parecen utilizarse indistintamente para significar una misma idea: la mutación o alteración de la verdad, que en este caso tiene lugar en un instrumento privado. Además del sentido natural de las palabras ${ }^{21}$, la definición de falsedad como una forma de engaño aparece también etimológicamente ${ }^{22}$, e incluso del origen del término que se conecta con el engaño en la estafa. Surgen aquí las primeras dificultades para distinguir ambas conductas, aunque se han intentado salvar ${ }^{23}$.

Por otro lado, Garrido Montt, "El documento...", p. 199, relaciona derechamente la definición de documento con el bien protegido. Sostiene que la complejidad de los bienes en juego así como el reemplazo de la noción de "daño" por la de "peligro" hacen inadecuada una interpretación abierta del término. Declaración que se refuerza con la citada vinculación de los supuestos de falsedad con el bien protegido (El mismo, Derecho penal..., p. 52).

${ }^{19}$ Pacheco, El Código..., p. 258, admite esta distinción pero luego sostiene que la ley toma la palabra "falsedad" en términos genéricos para expresar precisamente todo mudamiento de verdad.

${ }^{20}$ Ver Calle Rodríguez, M. V., La falsedad documental inocua en la jurisprudencia española, Universidad Complutense de Madrid, Madrid, 1995, p. 15.

${ }^{21}$ Desde su sentido natural destaca la falta de conformidad con la realidad, "alteración o simulación de la verdad, con efectos relevantes". Aparece así ya en las Partidas, Ley 1ª título 7, p. VII: "Falsedad es mudamiento de la verdad". Cousiño Mac Iver, La falsificación..., pp. 21 y 22, la describe como esencia del delito de falsedad: una alteración de la verdad que destruye la genuinidad del documento y se construye, en la mayor parte de los códigos, sobre la base de la máxima romana "falsum est immutatio veritatis", que se traduce en las Partidas de la forma señalada.

22 "Falso" viene del latín falsus, participio pasivo de fallêre, "engañar". "Falsificado" está tomado del latín tardío falsificatus, dentro del mismo sentido. "Engañar”, por su parte, viene del latín ingannare, escarnecer, burlarse de alguien. De modo que desde su etimología está conectado con su efecto en otro, error o derechamente idoneidad de la conducta.

${ }^{23}$ En cuanto al origen, las falsificaciones y las estafas aparecen con una fuente común. Desde la idea original de "fraude" se separan las de "falsum" y "estafa". Finzi, C. A., La estafa y otros fraudes, Depalma, 
En cualquier caso, esta idea de mutación de verdad lleva a resumir las modalidades de falsedad en dos: forjar o crear y adulterar ${ }^{24}$. Con ellas, la relación con la estafa va más allá del perjuicio, como formas de engaño propias de la estafa. Tanto así que ambas figuras se han llegado a distinguir por el perjuicio, que en principio las unía o incluso identificaba. En este sentido, Ortiz ${ }^{25}$ resuelve el concurso aparente entre ambos tipos a favor de la estafa al entender que las falsedades se consuman con la conducta engañosa y el perjuicio es un elemento ajeno necesario para castigar una condición de punibilidad. Conecta la conducta de falsedad con un objeto de tutela propio, la fe pública. A pesar de ello, sigue vinculando la falsedad con la estafa. Jakobs ${ }^{26}$ afirma esta relación por la actual concepción de falsedad como medio para atacar derechos concretos que coincide con una forma de autoría mediata por un instrumento que yerra (una conducta del sujeto que se comporta en un supuesto de error $)^{27}$, pero destaca la antigua idea de mudamiento de verdad como resultado mismo del delito, una dañosidad propia. Manifiesta que la abstracción de este objeto normativo demandó una concreción que sigue dos caminos: la remisión a delitos contra derechos particulares que degenera la falsedad en el citado medio de ataque y la vinculación de la fe pública con los documentos privados. Admite que el problema de ambos caminos es que la falsedad pierde su referencia normativa,

Buenos Aires, 1961, pp. 15-19 destaca uno de los orígenes de la estafa en el crimen falsi (además del crimen furti y del estellionatus), donde la variedad de conductas criminosas dificulta la determinación de los elementos de este crimen, que comparten como requisito común la modificación de verdad. Rechaza la remisión que hace Carrara del estellionato a la falsedad por el carácter privado del primero, a diferencia del crimen falsi. Sin embargo, sí advierte la confusión que se origina en la Edad Media con la creación de un nuevo falsum que incluye el fraude patrimonial y destaca el intento por superar el desorden en el s. XVII. Así, Feuerbach, P. J. A. R. von, Tratado de Derecho penal, traducción de la $14^{\mathrm{a}}$ ed. alemana por Zaffaroni, Eugenio Raúl; Hagemeier, Irma, Hammurabi, Buenos Aires, 1989, § 415, p. 271.

${ }^{24}$ Groizard y Gómez de la Serna, A., El Código Penal de 1870 concordado y comentado, Imprenta de D. Timoteo Arnaiz, Burgos, 1874, t. III, p. 624, manifiesta que la alteración de la verdad puede hacerse de dos modos, uno material (fabricar o crear) y otro no material (constar como cierto un hecho falso). En legislaciones comparadas se prefieren estas formas como verbos rectores. Por ejemplo, "herstellen" (fabricar o crear) y "verfälschen" (adulterar), además de "brauchen" (utilizar), en el § 267 del StGB alemán; "forma" o "altera" en el art. 485 del C.P. italiano; "hace" o "adultera" en el art. 427 del C.P. peruano; "hacer" o "adulterar" en el art. 292 del C.P. argentino; "falsificar" en todo o parte un documento o "alterar" en el art. 298 del C.P. brasileño; el art. 441-1 del C.P. francés habla simplemente de "toda alteración fraudulenta de la verdad". Esta tendencia siguió la discusión en nuestro país, reflejada en el art. 243 del Anteproyecto de Código Penal de 2005 elaborado por la Comisión Foro Penal: "forjar" o cometer falsedad haciendo "cualquier alteración", en Polit.crim, $\mathrm{N}^{\circ} 1, \mathrm{D} 1$, p. 53.

${ }^{25}$ Ortiz, P., "La falsificación de instrumento privado (ensayo de construcción jurídica del delito en Chile)”, en Revista de Ciencias Penales, t. VII, N. ${ }^{\circ} 3$, 1944, pp. 211 y 212.

${ }^{26}$ Jakobs, G., Falsedad documental. Revisión de un delito de engaño, traducido por López Barja de Quiroga, J.; Rey Sanfiz, L. C., Marcial Pons, Madrid, 2011, pp. 32, 34, 35.

${ }^{27}$ Esta tesis se ha desarrollado para la conducta de engaño en el delito de estafa. Así, Politoff Lifschitz, S., “Cometer' y 'hacer cometer': Desarrollo y significación actual de la noción de autoría mediata”, en Nieto Martín, A. (coord.), Homenaje al Dr. Marino Barbero Santos in memoriam, Ediciones Universidad Castilla - La Mancha, Universidad de Salamanca, Cuenca, 2001, pp. 1268-1273; Kindhäuser, U., La estafa como autoría mediata tipificada, traducido por Perdomo Torres, J. F., Universidad de Externado de Colombia, Bogotá, 2002, passim. 
por eso se preocupa de la antijuridicidad de la mutación de la verdad. Esta perspectiva cuestiona la naturaleza patrimonial de la falsedad ¿Se trata de un engaño de la misma clase que el de la estafa?

\subsection{Idoneidad de la falsedad}

Fijada la noción de falsedad como engaño, interesa ahora observar su modalidad. Vimos que en la estafa no parece preocupar la naturaleza del engaño principalmente por su identificación con el perjuicio patrimonial desde su descripción típica. Más que los términos de la ley en la estafa, importa la idoneidad del engaño o el engaño bastante frente a la disposición patrimonial ${ }^{28}$, que explica de algún modo la incorporación del error y de esta disposición como elementos distintos, pero que ligan el engaño a la lesión patrimonial. Aquí destaca la discusión del "elemento error" que se ha generado frente a la aptitud del engaño, en cuanto no sería un efecto distinto, sino un criterio para determinar tal aptitud o idoneidad. Esta idea es relevante cuando también se habla de error como un elemento necesario en la falsificación, ya como otra exigencia o conectado con la aptitud de la falsedad ${ }^{29}$. Incluso tiene mayor interés en este delito desde que en la misma ley aparecen reclamos de suficiencia en supuestos de falsedad. En este sentido, destaca el $N^{\circ} 4$ del artículo 193: faltar a la verdad en la narración de "hechos sustanciales", pues se registra en la historia de su establecimiento que tal mención se incorpora precisamente para dejar fuera la alteración insignificante, en cuanto "no produce resultado alguno en el sentido del documento" y "no puede ser causa bastante para condenar" (Sesión 151 de 9 de junio de 1873). También se subraya la modalidad del $\mathrm{N}^{\circ} 6$ de esa disposición al hablar de cualquier alteración en documentos verdaderos que "varíe su sentido" ${ }^{30}$. Se destaca la magnitud del engaño. ¿Es esta la idoneidad del engaño, un problema de entidad? ¿Entidad para qué?

${ }^{28}$ En general, Etcheberry, A., Derecho penal. Parte especial, $3^{\text {a }}$ ed., Editorial Jurídica de Chile, Santiago, 1998, t. III, pp. 392-402. Hernández Basualto, H., "Normativización del engaño y nivel de protección de la víctima en la estafa: lo que dice y no dice la dogmática”, en Revista Chilena de Derecho, vol. 37, $\mathrm{N}^{\circ} 1$, 2010 , pp. 21-25, expone cierto cuestionamiento a la aplicación de esta tesis porque no se imponen mayores exigencias de idoneidad del engaño y porque está pensado para delitos de "heterolesión" y no de "autolesión" como la estafa. El mismo, "La estafa triangular en el derecho penal chileno, en especial la estafa procesal", en Revista de Derecho, T. XXIII, N 1, 2010, p. 203, distingue estafa de hurto por autoría mediata en el caso de la llamada estafa triangular.

${ }^{29}$ Ruiz Pulido, G., "Una sentencia insólita”, en Revista de Derecho, Consejo de Defensa del Estado, N² 2000 , p. 5 , habla de una falsedad "suficientemente eficaz para conducir al error común...". http://www.cde. cl/wps/wcm/connect/ccfe12004fbf62flaef8af46ce4e7365/22.pdf?MOD=AJPERES; el mismo, "Instrumento..”., 2002 , pp. 64-66 y 81, alude a una idoneidad bastante para que la víctima sea "conducida a la aceptación de la falsedad o falsificación”. Se apoya también en normas del C.P. que remiten falsedades groseras o evidentes a otro título (engaño), aunque no se contempla específicamente para el caso de documentos (arts. 171, 179 y 184). En igual sentido, Garrido Montt, Derecho..., p. 64.

${ }^{30}$ A pesar de la discusión sobre su procedencia cuando se trata de instrumentos privados, interesa el peso o magnitud de la falsedad frente a sus efectos. 
La idoneidad o aptitud reclaman un objeto de referencia, pues tiene que ver con la adecuación a algo. En este sentido, tiene especial relevancia la propuesta de Gómez Benítez ${ }^{31}$ respecto del error como referencia del nivel de idoneidad de la estafa dentro del ámbito de la teoría de la imputación objetiva ya en 1985: el error define el nivel normativo de engaño bastante para afectar el patrimonio, como exigencia previa a la imputación objetiva del resultado. El error determinaría el engaño relevante, en cuanto crea un riesgo relevante para el bien protegido ${ }^{32}$, el patrimonio. Así aparece como un criterio normativo que vincula la conducta con el objeto de la norma, un criterio que podríamos calificar de imputación objetiva de la conducta ${ }^{33}$. En nuestro medio se ha hecho este alcance jurídico con relación a la idoneidad de la conducta ${ }^{34}$. Ocurre que este enfoque normativo en los términos planteados por Gómez Benítez refuerza las ideas de Cousiño ${ }^{35}$, cuarenta años antes, no solo frente a la idoneidad de la conducta de false$\operatorname{dad}^{36}$, sino también respecto de la necesidad de que exista un "vínculo de idoneidad" con el perjuicio, de modo que tal perjuicio sea consecuencia directa e inmediata de la falsificación. Nexo que coincide con la llamada "relación de riesgo" en la imputación objetiva del resultado ${ }^{37}$.

${ }^{31}$ Gómez Benítez, J. M., "Función y contenido del error en el tipo de estafa", en Anuario de Derecho Penal y Ciencias Penales, T. XXXVIII, Fascículo I, 1985 pp. 335, 337-340. Lo sigue en nuestro medio, Balmaceda Hoyos, G., Araya Paredes, I., "Engaño en la estafa: ¿una puesta en escena”, en Revista Estudios Socio-Jurídicos, 2009, 11, (2), pp. 25-31 y 34. También en términos normativos, Piña Rochefort, J. I., Fraude de seguros. Cuestiones penales y de técnica legislativa, Editorial Jurídica de Chile, Santiago, 2006, pp. 50-54, se desvincula del análisis causal de los elementos de la estafa en la línea de Jakobs y Nuria Pastor.

32 “... porque sólo esas conductas crean o incrementan el riesgo de que se produzca el resultado típico".

${ }^{33}$ Esta idea destaca la conducta como objeto valorado y subraya la distinción entre juicios de valoración ex ante y ex post. A este respecto interesa la distinción de juicios de peligro que realiza Hirsch, H. J., "Peligro y peligrosidad", traducido por E. Sola Reche, en Anuario de Derecho Penal y Ciencias Penales, vol. XLIX, fasc. II, 1996, pp. 510-513, al separar la peligrosidad (aptitud ex ante) del peligro (estado ex post).

${ }^{34}$ Labatut Glena, G., Derecho penal, $7^{\mathrm{a}}$ ed., actualizada por Zenteno Vargas, J., Editorial Jurídica de Chile, Santiago, 2005, t. II, pp. 54 y 55. Garrido Montt, Derecho..., p. 64, conecta la entidad de la conducta con el bien protegido, aunque para los documentos auténticos. Entiende que la falsedad material grosera no consume el tipo que tiene por fin proteger la fe pública. Requiere una alteración que "induzca a error a cualquiera y además supone una modificación del sentido o de los efectos que tenía el documento verdadero". En términos más expresos, Politoff, S., Matus, J. P., Ramírez, M. C., Lecciones de Derecho penal chileno, parte especial, $2^{a}$ ed., Editorial Jurídica de Chile, Santiago, 2006 p. 562, afirman que no existe falsificación en la fabricación burda de un documento "que nadie podía creer en la fe que se le quiere atribuir, faltando en este caso la antijuridicidad material del delito".

35 Cousiño Mac Iver, La falsificación..., pp. 31 y 41.

36 Hernández Basualto, "Normativización...", pp. 12 y 13 reconoce que la relación con esta tesis es hasta "natural", en la medida en que la teoría de la imputación objetiva tiende a fundar límites de la "imputación jurídico-penal”, aunque critica esta idea. Entiende que la diligencia o credulidad de la víctima solo incide en el error y no en la conducta engañosa, independiente de la acción de la víctima. Ciertamente su conducta solo puede incidir en la consumación del delito, pero eso no impide ni niega la consideración de criterios generales tanto para la interpretación de los tipos como para su imputación.

37 Así, particularmente, Mir Puig, S., "Significado y alcance de la imputación objetiva en Derecho penal”, en AA.VV., Modernas tendencias en la ciencia del Derecho penal y en la criminología, Universidad Nacional de Educación a Distancia, Madrid, 2001, pp. 394 y ss. 
La determinación del "engaño relevante" se conecta entonces con el fin de la norma. Desde esta perspectiva, tiene sentido definir el engaño en la estafa como un engaño patrimonial, que cree un riesgo para la afectación del patrimonio al suscitar la disposición patrimonial de otro. Ahora bien, ¿se mantiene esta clase de engaño en la falsificación de instrumento privado? Al menos, puede cuestionarse si se trata de documentos no mercantiles, aunque se requiera perjuicio de otro, si el bien que se protege en las falsedades no es el patrimonio ajeno, llámese: fe pública, fe probatoria, seguridad del tráfico jurídico, confianza en las relaciones jurídicas, funcionalidad del documento, etc. Este cuestionamiento se reafirma con la citada introducción de falsificaciones de instrumentos privados mercantiles que no exigen perjuicio. Por de pronto, se llama la atención acerca de la modalidad de la conducta engañosa en el delito de falsedades dentro de los términos legales, la mutación de verdad delimitada por los supuestos del artículo 193, y frente al objeto de la norma. La mera exigencia de perjuicio de tercero no limita la forma de conducta a un engaño patrimonial. En cambio, el examen del objeto sobre el que recae el comportamiento sí influye en las modalidades sancionadas.

\section{Objeto de falsificación: "instrumento privado"}

Hemos visto que la exigencia de ese perjuicio de tercero marca la diferencia entre la falsificación de documentos públicos y la de instrumentos privados. La suma del perjuicio se explica por la clase de objeto que repercute en la definición de la conducta de falsedad. Algo nos dice esta diferencia, que incide en la magnitud de la conducta delictiva. La menor penalidad de la falsificación de instrumentos privados a pesar de la exigencia de perjuicio de otro refleja la menor gravedad de la conducta precisamente con base en este especial objeto. Pacheco ${ }^{38}$, al comentar la norma española fuente de la nuestra, afirma que la distinción de pena en ambas clases de falsedades se explica por la "gran diferencia" entre un delito y otro, "atendida la fe pública, y la alarma de la sociedad”. Funda la variedad de penas según el objeto falsificado en su alcance respecto del contenido de la norma, qué se tutela y cómo se afecta. La lesividad o, derechamente, antijuridicidad de la conducta de falsedad le preocupa ya antes de definir esa conducta, al precisar qué entiende por "documento". En su noción general, como todo lo que da o justifica un derecho, asegura una acción o que "prueba aquello en que tiene interés una persona" 39 , destaca la relevancia del documento mismo para justificar ya la criminalidad del comportamiento por la entidad de sus repercusiones.

"Si la importancia de tales documentos se concibe bien por esta mera enunciación, no hay ciertamente necesidad de añadir nada acerca de lo criminal de sus falsificaciones. Semejante género de delitos tiende a conmover en todas sus transacciones,

38 Pacheco, El Código..., p. 307.

39 Pacheco, El Código..., p. 295. En esta línea, Irureta Goyena, J., Falsificaciones documentarias, Imp. Sarandi, S.L., 1958, p. 29, toma las palabras de Pessino para destacar la necesidad de que "exista en el documento cierta atingencia con la vida jurídica” de modo que su alteración sea materia de falsificación. 
en todos sus derechos, la sociedad entera. Faltaría, pues, a uno de sus primeros encargos la ley que no mirase este punto con toda la importancia que tiene en sî".

Esta explicación de Pacheco parece tener bastante sentido frente a la comentada sanción de falsificaciones de ciertos instrumentos privados mercantiles por sí misma, sin requerir causar un perjuicio para otro. Esta desvinculación del perjuicio revela la entidad de esta clase de instrumentos. El legislador ya hace una diferencia respecto de otros instrumentos privados en el delito de falsificación común, al castigar su falsificación con mayor pena (art. 197, 2). Es tal la relevancia de ella que incluso se asocian a los documentos públicos antes que a los instrumentos privados ${ }^{40}$. Aunque nuestra ley los considera privados, la diferencia de trato señalada exige delimitarlos. De todas formas, la mayor distinción se da frente a los documentos públicos, que se separan en general de los instrumentos privados por la intervención de un funcionario público que da fe del documento con las solemnidades legales ${ }^{41}$.

Parece evidente la distinción del documento público desde esos parámetros, pero no es tan simple cuando se examina la realidad, la multiplicidad de casos. Por ejemplo, qué ocurre con el certificado que emiten empresas certificadoras según la Ley No 20.393 que establece y regula la responsabilidad de personas jurídicas por determinados delitos (lavado de dinero, financiamiento del terrorismo y cohecho de funcionario nacional y extranjero). Dentro del modelo de responsabilidad que establece, contempla el control de un modelo de prevención de delito y deja la certificación de su adopción e implementación a personas que según tal ley "cumplen una función pública en los términos del artículo 260 del Código Penal” (art. 4). Además de la función, los entes certificadores han de estar registrados en la SVS y sometidos a sus disposiciones. ¿El certificado que emiten en el ejercicio de estas funciones y conforme a las disposiciones legales y reglamentarias es un documento público o auténtico o es un instrumento privado?

Nuestro Código Penal habla de documento público o auténtico y, a pesar de su referencia histórica al Código Civil por seguir al Código Penal belga en este punto, los términos pueden asimilarse a los españoles: que separa los documentos públicos de los oficiales (autenticidad también tiene un sentido de oficialidad) ${ }^{42}$. Los primeros serían

${ }^{40}$ Valdés Matus, De la falsificación..., p. 9 destaca, específicamente respecto de las letras de cambio, que por su naturaleza están llamadas a producir plena confianza en el público. De hecho, en la misma legislación española que nos sirve de fuente se trató el documento público u oficial junto con el documento mercantil, "De la falsificación de documentos públicos u oficiales y de comercio". Se observa una conexión desde lo que estos objetos alcanza. Fernández, P. J., Código Penal de la República de Chile esplicado y concordado, $2^{\mathrm{a}}$ ed., Imprenta Litografía y Encuadernación Barcelona, Santiago, 1899, pp. 330 y 331, expresa que el comercio se sustenta de la buena fe, "en esa natural confianza que los hombres se dispensan entre sî".

${ }^{41}$ Esta idea se sigue desde la historia de su establecimiento, que se remite a la legislación civil. En general, Etcheberry, Derecho..., t. IV, p. 157. Desde semejante concepción, el instrumento privado suele definirse en forma negativa, por la falta de intervención de un funcionario público. Ya Vera, Código..., p. 378.

42 "Oficial": "Que es de oficio, o sea que tiene autenticidad y emana de la autoridad derivada del Estado, y no particular o privado”. Etcheberry, Derecho..., t. IV, p. 160, hace hincapié en que la opción civilista fue de carácter terminológico y que el texto sustantivo no fue alterado. A partir de la modalidad de falsedad del $\mathrm{N}^{\circ} 8$ del art. 193 destaca la referencia a un documento oficial, que por tanto es un documento público. Ruiz 
los otorgados por sujetos que realicen una función pública, mientras que los segundos, aquéllos otorgados por una autoridad o funcionario del Estado ${ }^{43}$. Con relación al problema de la naturaleza del certificado que emiten las empresas certificadoras, se podría entender que la intervención de una autoridad pública, que represente al Estado, es necesaria para que se trate de un documento auténtico, pero para que sea público basta con que sea otorgado en el ejercicio de una función pública y según las formas establecidas $^{44}$. Con estos criterios, aun en el caso expuesto, tiene sentido la referencia a la fe pública, como bien que se afecta por conductas que fabriquen o alteren la veracidad en esta clase de documentos. A contrario sensu, la no intervención de una autoridad pública o de un sujeto que ejerza una función pública dificulta la relación con la fe pública como objeto general de tutela.

Groizard $^{45}$ explica que los escritos son privados o públicos según reciban su autoridad y fuerza del carácter particular de su otorgante o de las funciones públicas de quienes intervienen. Enseña que la falsificación de los privados no alcanza derechos vinculados con el orden de una autoridad superior o con funcionarios depositarios de fe pública, sino solo los derechos de los particulares. En esta omisión justifica la redacción española, que contemplaba también el mero ánimo de causar perjuicio (hoy es el único supuesto que se mantiene), y comprende su consideración como "delito de defraudación" en algunas legislaciones ${ }^{46}$. Por ahora, cabe advertir que la definición de instrumento privado se conecta tanto con la exigencia de perjuicio de tercero, como con aquello que la norma tutela, el bien jurídico afectado por la falsificación de este objeto. De allí que sea fundamental precisarlo, no sólo frente a los documentos públicos.

A pesar de los parámetros señalados para definir los documentos públicos, todavía falta establecer la noción de instrumento privado para seguir con la exigencia del perjuicio cuando la conducta de falsedad es, en general, la misma en ambos delitos de falsedad. Nuevamente la realidad nos complica la determinación de un instrumento privado y su distinción de los que tienen carácter mercantil. Si miramos, por ejemplo, el caso de los

Pulido, "Instrumento...", pp. 72 y ss., comienza admitiendo que el documento público y el auténtico se utilizan como sinónimos respecto de su "fuerza probatoria y de su amparo penal", pero luego entiende que los auténticos son el género y dentro de ellos estarían los públicos y los oficiales. Los primeros emanarían de entes públicos y los segundos no requerirían un origen público, sino que atiendan a su tráfico dentro de la administración del Estado, todo el que circula al interior de ella o sale al exterior una vez cumplido el procedimiento jurídico respectivo.

43 Pacheco, El Código..., pp. 295 y 296.

${ }^{44}$ Estas referencias pueden apoyarse más allá de la amplia noción de empleado público del art. 260 del C.P., por un cargo o función pública. Así, la Convención Contra la Tortura y Otros Tratos o Penas Crueles, Inhumanas o Degradantes, de 1984 toma para la definición de torturas tanto a quien es funcionario público como a cualquiera que realice tal función (art. 1). Aquí Ruiz Pulido, "Instrumento...”, pp. 75-82, cabe tener presente su amplia noción de documento oficial, que incluye instrumentos privados certificados o reconocidos por una autoridad del Estado o que hayan de producir efectos en la administración del Estado.

45 Groizard y Gómez de la Serna, El Código..., pp. 607, 608, 633, 636 y 637.

46 Esta última declaración puede entenderse en cuanto tiene a la vista al C.P. español de 1822, que coincide con la nuestra: contempla solo la hipótesis de causar perjuicio (con perjuicio); elemento que en nuestro medio motiva tales interpretaciones. 
“documentos electrónicos”, recordemos que existe una ley que los considera documentos y sin embargo no resulta tan clara la procedencia de los delitos de falsificación del Código Penal. El cuestionamiento se apoya también en la noción general de instrumento como escrito o papel donde se registren ideas, pensamientos, acciones con cierto alcance jurídico. En este sentido se ha decantado la doctrina nacional en general, sin sujeción total a los límites de la concepción civil ${ }^{47}$. La escrituración no se opone a una noción amplia de instrumento privado, no limitada a la consagración de obligaciones o de su solución, como lo sostiene Cousiño ${ }^{48}$ al recurrir al elemento gramatical por sobre el histórico.

Este autor advierte que la expresión “instrumento" que adopta la Comisión Redactora no se sigue en otros cuerpos normativos que utilizan el término en sentido amplio, como documento. Con esta divergencia pone énfasis en la interpretación gramatical con el sentido natural de las palabras, que lo concibe como documento: "escritura, papel o documento con que se justifica o prueba algo". Apoya esta noción teleológicamente a partir de la "fe probatoria" como bien protegido. Así no distingue instrumento de documento y lo define como cualquier escrito que pueda servir de medio de prueba ${ }^{49}$. En realidad e incluso con base histórica (como remisión terminológica), el instrumento es un documento cuya forma escrita se deduce de las modalidades de falsedad y que conforme al mero sentido natural de la expresión "documento" registra datos, declaraciones o conductas que sirven de prueba para particulares que lo suscriben, sin intervención de un funcionario público o fuera del ejercicio de una función pública. En este sentido, pueden observarse tres funciones: de perpetuidad (fijación material de pensamientos o declaraciones); de prueba (para las relaciones a las que se refiere) y de garantía (identificación del otorgante como garante de la declaración) ${ }^{50}$. Precisamente

${ }^{47}$ En general se admite la escrituración como base, pero no se limita el contenido a la consagración de obligaciones y su extinción. Así, Garrido Montt, "El documento...", pp. 199 y 200, rechaza consideraciones en formatos distintos de la escritura y no solo se apoya en consideraciones históricas, sino también en las modalidades de falsedad: ellas suponen formas escritas. Con una tesis amplia Etcheberry, Derecho..., t. IV, pp. 156 y 157, ni siquiera se limita a escritos. Concibe documento como "todo objeto que representa un hecho o una manifestación de pensamiento, emanada de un autor y fijado en forma permanente”. También Silva Silva, H., Manual de Derecho penal. Delitos especiales, Thomson Reuters, Santiago, 2010, pp. 22, 23, 33-35, sigue una noción amplia que incluye los electrónicos. Autores anteriores, como Vera, Código..., pp. 378 y 379, toman las disposiciones civiles, probablemente siguiendo a Pacheco, El Código..., p. 307.

${ }^{48}$ Cousiño Mac Iver, La falsificación..., pp. 14-21.

${ }^{49}$ En general, Del Río, R., Derecho penal, Nascimento, Santiago, vol. 3, 1935, p. 150; Valdés Matus, De la falsificación..., pp. 16, 23-26; Labatut Glena, Derecho..., p. 53; Garrido Montt, Derecho..., pp. 52-57. También se ha consagrado así en textos comparados, por ejemplo: art. 427 del C.P. peruano habla de un documento "que pueda dar origen a derecho u obligación o servir para probar un hecho"; art. 441-1 del C.P. francés se refiere a la falsedad "en un escrito o en cualquier otro medio de expresión del pensamiento que tenga por objeto o que pueda tener como efecto constituir la prueba de un hecho con consecuencias jurídicas o de un derecho"; art. 221 del C.P. colombiano alude a "documento privado que pueda servir de prueba".

${ }^{50}$ Así se describen para este delito en Alemania, aunque no se distingue entre documento público y privado. Cramer / Heine, "§ 267”, en Schönke / Schröder, Strafgesetzbuch Kommentar, 28ª ed., Beck, München, 2010, p. 2502. Bacigalupo Zapater, E., "Documentos electrónicos y delitos de falsedad documental", en Revista Electrónica de Ciencia Penal y Criminología, 04-12, 2002, pp. 3, 5, 7 y ss., se ocupa de estas funciones en los documentos electrónico también por la falta de claridad que existe en España al no haber un tipo especial 
desde esta triple función, Rodríguez Collao y Vera Vega ${ }^{51}$ concretan el bien jurídico común a toda falsedad (seguridad del tráfico) en la afectación de la funcionalidad del documento $^{52}$. Por su parte, para determinar cuáles instrumentos son mercantiles ha de recurrirse a las definiciones técnicas, las disposiciones del Código de Comercio. Además de depender de sus valoraciones, cabe hacer presente que no todos los documentos de esta clase son objeto del delito, partiendo por las mismas letras de cambio que cita el art. 197 de ejemplo y cuya falsedad se castiga en otra ley (art. 110 del DFL $\mathrm{N}^{\circ}$ 3). Otro tanto ocurre con las tarjetas de crédito y de débito, sin contar con los proyectos descritos.

En síntesis, la noción de falsedad no implica per se un contenido económico o patrimonial, pero su alcance depende del objeto sobre el que recae. Éste es un documento que tampoco tiene en sí mismo una connotación económica, salvo si tiene carácter mercantil. Habrá que ver qué ocurre con el perjuicio de tercero que exige el tipo penal que castiga la falsedad de instrumentos privados.

\section{El SENTIDO DEL “PERJUICIO DE TERCERO”}

Resulta lógico dedicarse al estudio del elemento perjuicio (“con perjuicio de tercero”) que exige como requisito distintivo la falsificación de instrumento privado frente a la falsificación de documentos públicos, cuando la clase de conducta engañosa es común aunque con cierta distinción de alcance según su objeto material. Si bien esta separación de efectos no suele destacarse en la conducta, sí se advierte alguna preocupación por este perjuicio. Así, la principal discusión en la dogmática nacional se produjo en el año 1944 y giró en torno su calificación como un elemento objetivo del tipo penal o como una condición de punibilidad.

Cousiño ${ }^{53}$ entendió que se trataba de un elemento objetivo por su conexión con la conducta de falsedad: no cumpliría con las cualidades propias de una condición de punibilidad, ajena al comportamiento delictivo. Se recuerda que habla incluso de un "vínculo de idoneidad" entre falsedad y perjuicio. Por su parte, Ortiz ${ }^{54}$ califica el perjuicio como una condición de punibilidad porque estima que el delito

\footnotetext{
de falsificación como en Alemania. Entiende que ella se puede dar, pero admite que sería conveniente una revisión. Interesante resulta la advertencia que hace respecto de las innovaciones: "Cada vez que la realidad social presenta a los juristas nuevas situaciones, la primera aproximación a la solución del problema suele ser llevada a cabo mediante un análisis de problemas análogos del pasado, que hoy pueden estar ya olvidados como tales".

${ }^{51}$ Rodríguez Collao, L., Vera Vega, J., "El bien jurídico protegido en los delitos de falsedad”, en Revista Escuela de Derecho, Año 5, Número 5, 2004, pp. 130-135.

52 Resulta interesante rescatar las funciones del documento frente a los efectos de la conducta, como lo ha tomado el Tribunal Supremo español por ejemplo con relación al objeto de la norma, la antijuridicidad de la conducta, que va más allá de la perturbación de un medio de prueba. Así ya, STS de 18 de noviembre de 1998, 828/98; STS de 26 de junio de 1999, 911/99.

53 Cousiño Mac Iver, La falsificación..., pp. 31, 38-42.

${ }^{54}$ Ortiz, "La falsificación...", pp. 207, 208, 212.
} 
ya está consumado con la conducta de falsificación y que el perjuicio se produce después como exigencia para castigar. La distinción no es irrelevante porque tiene consecuencias respecto de la sanción de fases previas a la consumación, que estarían prohibidas en caso de aceptar la condición objetiva de punibilidad ${ }^{55}$. También veremos que esta comprensión repercute en la dañosidad misma de la falsedad y en la naturaleza de este perjuicio extra.

La discusión ya no se presenta. Existe consenso sobre la calidad de este perjuicio como un elemento objetivo del tipo de falsificación de instrumento privado. En realidad, este delito no suele llamar la atención respecto de sus elementos ni de sus alcances por la referida conexión con la estafa precisamente a partir del perjuicio. Esto se explica por su interpretación económica o patrimonial. Así se decanta la doctrina nacional actual que trata esta falsificación como una especie de estafa ${ }^{56}$, caracterizada por el medio empleado. En el mismo sentido se orientan nuestros tribunales ${ }^{57}$. La verdad es que semejante interpretación parece evidente cuando se trata de un instrumento privado mercantil (art. 197 , inciso $2^{\circ}$ ), por su contenido patrimonial. Por eso no sorprenden sentencias que se pronuncien en este sentido, aunque se destaque la "idoneidad del engaño".

\begin{abstract}
Así, la SCA de Santiago de 14 de noviembre de 2008, Rol: 1122-2007:
" $1{ }^{\circ}$ Que si bien atendida la naturaleza del delito de estafa, éste se caracteriza por el engaño adecuado y bastante de que se vale el culpable para captar la voluntad del sujeto pasivo, induciéndolo a error al dar la apariencia de veracidad al hecho falso, tanto la doctrina como la jurisprudencia están contestes en que, si el agente debió realizar numerosas maquinaciones fraudulentas, entre otras, cometer falsedades o hacer uso de ellas en diversos instrumentos privados mercantiles, existe un concurso aparente de leyes entre la estafa y la falsedad documental, que se resuelve a favor de esta última por el principio de especialidad".
\end{abstract}

${ }^{55}$ Ortiz, "La falsificación...", pp. 210-212, resuelve el problema con el delito de estafa, siempre que se busque un perjuicio patrimonial, pues en ese delito es elemento del tipo y permite, por tanto, la sanción de fases previas a la consumación. Aunque relaciona ambos delitos, la solución frente al problema de concurso no es igual a la de Cousiño precisamente por la forma en que estructura el delito de falsificación y que va más allá de la discusión que aquí se fija, según veremos.

56 Así, Etcheberry, Derecho..., t. IV; pp. 174, 176-178 Politoff; Matus; Ramírez, Lecciones..., pp. 451, 556, 570; Hernández Basualto, “Uso indebido..”, pp. 36 y 37; Silva Silva, Manual..., pp. 12 y 25.

${ }^{57}$ SCS de 9 de diciembre de 2010, Rol: 3481-2009; SCA de Concepción de 8 de enero de 2008, Rol: 2202-2005; SCA de Santiago de 29 de junio de 2006, Rol: 7883-2006; SCS de 31 de agosto de 2005, Rol: 796-2003; SCA de Santiago, de 16 de junio de 2000, Rol: 51647-1998; Así incluso se ha sostenido frente a la apropiación indebida, un tipo especial de ella, por ejemplo: SCA de San Miguel de 16 de junio de 2010, Rol: 10-2010. En otro sentido, la SCA de Santiago de 12 de noviembre de 2009, Rol: 2413-2009, considerando los principios de especialidad y de consunción, entiende que la estafa abarca la falsificación, "queda subsumida en el engaño propio de toda estafa". Si es así, no se comprende realmente qué justifica la existencia de este delito de falsificación. 
¿Habrá de mantenerse esta interpretación en otros instrumentos privados? La respuesta parece seguir siendo afirmativa por la exigencia del perjuicio y la falta de consideración de la clase de engaño, como si aquel elemento definiera la falsificación de instrumento privado a modo de "engaño patrimonial", al igual que la estafa y a diferencia de la falsificación de documentos públicos. A partir de esta idea, la relación entre falsificación y estafa se ubica todavía en el llamado concurso aparente de leyes penales que suele resolverse por especialidad a favor de la falsificación de instrumento privado $^{58}$. Cousiño también prefería este delito pero por consunción antes que especialidad $^{59}$. Ortiz ${ }^{60}$, aunque considera que se trata de un concurso aparente, llega a una solución distinta. Prefiere el delito de estafa precisamente por estimar el perjuicio como condición de punibilidad que queda fuera de la conducta delictiva. Al bastar la falsedad para consumar el tipo (el perjuicio solo se necesitaría para castigar), el delito de estafa es más amplio, incorpora el perjuicio además del engaño. Resuelve entonces aplicando el principio de consunción en vez del de especialidad. Este mismo camino se sigue en España por la forma en que se concibe el perjuicio ${ }^{61}$. El art. 395 del Código Penal habla de cometer falsedad en documentos privados (que distingue de los públicos y de los mercantiles) "para perjudicar a otro", ya ni siquiera contempla el "con perjuicio" que finalmente fue la única hipótesis que -como veremos- nuestro legislador tomó.

Puede ser que esta solución de Ortiz, como la española, se explique más allá de la estructura formal del perjuicio (como elemento objetivo o como condición de punibilidad) y tenga que ver con el objeto de la norma que sanciona la conducta de falsificación. De hecho, este autor cuestiona la existencia del perjuicio por entender que la conducta de falsedad es la que "encierra en sí el resultado que caracteriza la consumación del delito”, la lesión de la fe pública ${ }^{62}$. Más que la desconexión del perjuicio con la falsedad, su calificación del perjuicio tiene sentido frente al contenido de la norma que castiga las falsedades. Advierte no sólo que la fe pública es objeto de este delito, sino que "no se trata de la protección de otros bienes jurídicos”. Esta declaración es coherente con la crítica que le formula a Cousiño respecto de la confusión entre el perjuicio que este tipo exige y la ilicitud, su antijuridicidad ${ }^{63}$. A pesar de esta visión que refiere al bien protegido, no cabe prescindir del elemento perjuicio si el legislador lo exige y como efecto de la falsedad.

\footnotetext{
${ }^{58}$ En general, Etcheberry, Derecho..., t. IV; p. 177. También lo sostiene así Garrido Montt, Derecho..., p. 95, pero en caso de que el perjuicio sea patrimonial, pues admite que puede tener otra naturaleza.

59 Cousiño Mac Iver, La falsificación..., pp. 48 y 49, solo "en el supuesto de que lo dicho fuere errado" sostiene el de especialidad.

${ }^{60}$ Ortiz, “La falsificación...", pp. 210-212.

${ }^{61}$ Ver Climent Durán, C., Código Penal con jurisprudencia sistematizada, $4^{\mathrm{a}} \mathrm{ed}$., Tirant lo Blanch, Valencia, 2011 , pp. 2110 y 2111.

${ }^{62}$ Ortiz, "La falsificación...," p. 208.

63 Ortiz, "La falsificación...", p. 214.
} 


\section{Cuestionamiento de la existencia del "perjuicio de otro"}

A partir del establecimiento de este elemento, se observa que la consagración del perjuicio no se fundó en consideraciones objetivas. La falsificación de instrumentos privados se toma de la legislación española, específicamente del art. 228 del Código Penal de 1850. Esta norma castigaba al que "con perjuicio de tercero o con ánimo de causárselo”, cometiere determinadas falsedades en un documento privado. La Comisión Redactora eliminó la segunda posibilidad que remitía al mero ánimo de causar el perjuicio. Los redactores entendieron que no era necesario, pues todo delito se comete con dolo (Sesión $43)^{64}$ y no advirtieron que estaban excluyendo un segundo supuesto objetivo, el que no requiere causar perjuicio. Fundamentan su supresión en consideraciones subjetivas y no se elimina un elemento subjetivo del delito, sino otra hipótesis de comisión.

El legislador nacional no tuvo en cuenta una dañosidad especial, distinta de su fuente española, por lo que este perjuicio podría faltar. Independientemente de consideraciones de lege ferenda, la redacción legal impide prescindir de él, aunque no coincida con la falsedad de documentos públicos ni explique la relevancia de las falsedades ${ }^{65}$. Otra situación es que haya de ser una lesión patrimonial. La común aceptación de esta calidad motivó su investigación, especialmente por la amplitud de las formas de engaño en el tipo de estafa. ¿Qué justifica la existencia de un delito especial de falsificación cuando la estafa permite cualquier medio de engaño apto para afectar el patrimonio ajeno? Este delito de falsificación podría perfectamente no existir. Sin embargo, alguna relevancia parece tener la conducta de falsedad incluso con esta calificación del perjuicio, cuando se resuelve el problema de concurso entre ambos ilícitos por especialidad a favor de la falsificación, más aún cuando la opción se funda en el principio de consunción o en el de alternatividad por un bien jurídico especial afectado ${ }^{66}$. Algo adicional existiría en la falsificación de instrumentos privados. Esto se destaca con mayor fuerza en tesis que optan por un concurso de delitos ${ }^{67}$.

Esta posible diferencia muestra cierta entidad particular de la conducta de falsedad, coherente con su mayor sanción frente a la conducta de estafa, que motiva la reflexión sobre su lesividad. Así, la sentencia de la Corte de Apelaciones de Valparaíso de 20 de julio de 2010 (Rol: 547-2009) invalida la resolución de instancia que recalifica los hechos como falsificación y no estafa, por la falta de defensa adecuada frente a la mayor

${ }^{64}$ Se afirma que "siempre es necesario que haya dolo para que un acto se considere delito".

${ }^{65}$ Este límite ya lo indicaba Fernández, Código..., p. 328: "La lei ha creido necesario que a la falsificación siga un perjuicio de tercero para que el delito exista. I debemos acatar su determinación por mas que choque a los sentimientos de una severa moral".

${ }^{66}$ Se recuerda la preferencia de Cousiño Mac Iver, La falsificación..., pp. 48 y 49, por un principio de consunción y destaca la solución de Labatut Glena, Derecho..., p. 60, que resuelve por alternatividad: "debe prevalecer el precepto que tutela el bien jurídico más importante".

${ }^{67}$ Bañados, Código..., p. 185. Cousiño Mac Iver, La falsificación..., pp. 44 y 45, reconoce que esta es la tesis imperante incluso 20 años después que Bañados. Aun la tesis de Ortiz, que se decanta a favor de la estafa según el principio de consunción, muestra la independencia y relevancia de la conducta de falsedad, que satisface el tipo penal. 
gravedad del tipo de falsedad, distinguiendo el objeto protegido que afectan: afirma que esos delitos "no son de la misma especie y los bienes jurídicos que protegen, son diversos”. Esta diferencia puede vincularse con la falsificación, la conducta de engaño, y no necesariamente con la clase de perjuicio. Éste todavía podría ser patrimonial. ¿Es así? Si bien partir con el cuestionamiento de la existencia de este elemento no tiene sentido de lege lata ${ }^{68}$, el examen de su naturaleza sí la tiene cuando se remite la conducta de falsificación al tipo de estafa, sin revelar consideraciones especiales en torno a la conducta de falsedad. Entonces, ¿habrá que restringir la palabra "perjuicio" a una lesión patrimonial? El análisis que sigue pretende abordar este problema.

\section{Cuestionamiento de la naturaleza del perjuicio}

A pesar de la pacífica aceptación del elemento perjuicio como lesión al patrimonio ajeno, esta concepción no siempre se sostuvo en nuestro país. Justamente desde la exigencia del perjuicio, Cousiño ${ }^{69}$ admite que su consagración legal supuso una configuración objetiva de este delito. Semejante reconocimiento no lo lleva a una definición patrimonial de este elemento. De hecho, cuando se plantea el problema del concurso entre falsificación y estafa, afirma que la primera es un "fraude, que tiene por su contenido la potencia de dañar los derechos de otro; y, entre ellos, también el derecho de propiedad"70. Por eso es partidario del delito de falsificación por consunción si se alcanza este último derecho ${ }^{71}$. No asume una lesión patrimonial como requisito de la falsificación ni como definición del perjuicio. Derechamente se pregunta si puede haber otros bienes afectados $^{72}$. Así, mira la naturaleza del perjuicio y, más aún, indaga sobre la lesividad de la falsificación misma, como ya insinúa de la referencia de una "potencia" de dañar derechos de otro a la conducta de engaño (fraude) y de la remisión del daño mismo a la producción del perjuicio de otro.

Aunque la combinación de declaraciones sobre la conducta de falsedad y el perjuicio dificulta advertir su definición, tiene una tesis para ambos. Respecto del perjuicio,

${ }^{68}$ De todas formas su eventual supresión tiene especial interés cuando la legislación que suele servir de fuente a la nuestra no exige causar perjuicio a tercero como un elemento objetivo adicional. Por ejemplo, art. 395 del C.P. español ("para perjudicar a otro") o el $\$ 267$ del StGB ("para engañar en el tráfico jurídico": zur Täuschung im Rechtsverkehr). Otras legislaciones de interés en este sentido: art. 485 del C.P. italiano ("con el fin de procurar una ventaja para sí o para otro o de producir un daño a otro": al fine di procurare a sé o ad altri un vantaggio o di recare ad altri un danno,); el art. 298 del C.P. brasileño (únicamente exige falsificar o adulterar) y la falsedad ideológica del art. 299 (“con el fin de perjudicar un derecho, crear una obligación o alterar la verdad sobre un hecho jurídicamente relevante": com o fim de prejudicar direito, criar obrigação ou alterar a verdade sobre fato juridicamente relevante); art. 292 del C.P. argentino ("de modo que pueda resultar perjuicio"); art. 427 del C.P. peruano ("si de su uso puede resultar algún perjuicio”); art. 221 del C.P. colombiano ("El que falsifique documento privado que pueda servir de prueba, incurrirá, si lo usa, en...”).

${ }^{69}$ Cousiño Mac Iver, La falsificación..., p. 36.

${ }^{70}$ Un "fraude que se comete en daño del derecho de propiedad", Cousiño Mac Iver, La falsificación..., p. 46.

${ }^{71}$ Cousiño Mac Iver, La falsificación..., p. 47.

${ }^{72}$ Cousiño Mac Iver, La falsificación..., p. 8. 
expresa que hasta la fecha en que escribe se acepta en forma casi unánime que puede tratarse de cualquier clase, material o moral ${ }^{73}$. Advierte, eso sí, cierta inclinación de la jurisprudencia nacional hacia un perjuicio que se identifica con una lesión patrimonial. Considera que esta tendencia puede deberse a la influencia de la doctrina de Carrara ${ }^{74}$ que concibe esta falsificación como un delito contra la propiedad. Quizá este consenso que describe Cousiño explique el relativo desinterés por la calidad o naturaleza del perjuicio, mientras que su identificación con una lesión patrimonial sea posterior. Le preocupa este elemento frente a su relación con la conducta de falsedad (como elemento objetivo del tipo y no condición de punibilidad) y con la conducta de estafa (que prefiere la falsedad por consunción). Ambas preocupaciones encajan con el problema central que le ocupa, el bien que afectan las conductas de falsedad. Entiende que fe pública se concreta para toda falsedad documental en una "fe probatoria", confianza colectiva en documentos como medios destinados a probar un hecho cualquiera ${ }^{75}$.

Aun esa idea común de bien jurídico se separa del "perjuicio de otro" al afirmar que ese denominador no impide que la fe probatoria se radique en bienes particulares, como el honor o cualquier derecho protegido por la ley. Pone énfasis en la dañosidad de la conducta de falsedad, que refuerza con su noción de documento, al que atribuye en sí mismo relevancia jurídica ("potencia dañosa”) ${ }^{76}$. Se distinguen dos afectaciones o "perjuicios" cuando afirma que el reconocimiento de un bien común para los delitos de falsedad evita el "artificio" de recurrir al doble ataque de bienes jurídicos. ¿Será que está cuestionando la necesidad del perjuicio de tercero? No se pronuncia al respecto, sí se percata de la necesidad de concreción del bien protegido, que no por eso supone otro perjuicio. La tesis puede confundirse no sólo porque utiliza la expresión perjuicio en ambas situaciones, sino también por la definición de perjuicio como un requisito siempre necesario, implícito en toda falsedad ${ }^{77}$. Afirma que la única diferencia entre las dos clases de documentos radica en que si se trata de un documento público el perjuicio es solo potencial, mientras que si es privado debe ser real y efectivo. Entonces, ¿la mayor afectación se produce en caso de documentos privados, castigados con menos pena?

El bien protegido es el mismo y la diferencia radicaría en la forma en que se afecta. La real producción del perjuicio tiene sentido frente a la redacción que exige perjuicio de tercero (para instrumentos privados) y no por la conducta de falsedad, que se alcance un bien adicional. De otra forma no se entendería que respecto de un mismo bien jurídico

${ }^{73}$ Cousiño Mac Iver, La falsificación..., pp. 31-33. Bañados, Código..., p. 184, sin problema, expresa que también se refiere a los perjuicios contra el honor, que considera más perjudicial aún. Se apoya en jurisprudencia de tribunales franceses, así como de doctrina de autores belgas e italianos.

${ }^{74}$ La fuerza de Carrara en la doctrina de ese tiempo se puede observar en Irureta Goyena, Falsificaciones..., passim.

${ }^{75}$ Cousiño Mac Iver, La falsificación..., pp. 8, 27. Este mismo problema es el que muestra Jakobs para explicar el desarrollo de las tesis sobre el bien que afectan las conductas de falsedad, con cierta distinción entre la clase de documentos, a pesar de que en la legislación alemana no hay tipos distintos ni se exige perjuicio de otro.

\footnotetext{
76 Cousiño Mac Iver, La falsificación..., pp. 11, 30 y 49.

${ }^{77}$ Cousiño Mac Iver, La falsificación..., pp. 30 y 49.
} 
sea menos grave su afectación real que la potencial. En este sentido resulta útil recordar la confusión que advierte Ortiz de las ideas de Cousiño al identificar la ilicitud con la exigencia del perjuicio de tercero. La distinción resulta útil para terminar de reflexionar acerca de la naturaleza de este perjuicio.

\section{ANÁlisis CRÍtico DEL ELEMENTO PERJUICIO}

La naturaleza patrimonial de la conducta de falsedad se cuestiona desde el fin de la norma que sanciona las falsedades, si se define un bien propio distinto del patrimonio. Sin embargo, la distinción se complica cuando se trata de instrumentos privados y más aún cuando se exige expresamente perjuicio de tercero. Es fundamental el carácter de este objeto, cuando la conducta de falsedad coincide con la que recae en documentos públicos y se muestra particularmente en nuestro Derecho con la exigencia de tal perjuicio. Además, en la mayoría de los casos él es patrimonial. ¿Es la frecuencia de tales casos la que determina este delito de falsificación como un delito de estafa especial?

La respuesta afirmativa se pone en duda aquí desde el origen de la expresión. La historia del establecimiento de esta clase de falsificaciones que fijó la redacción final supuso una objetivación del tipo por la eliminación de consideraciones subjetivas que se consideraban obvias (el ánimo de causarlo) y no tuvo una connotación patrimonial. La raíz común de la falsedad con la estafa sí facilita la confusión, particularmente cuando se refiere a documentos privados, pero se mantiene no su distinción, que en realidad se completa por el fin de las normas. Antes, los límites legales examinados no suponen necesariamente una lesión patrimonial. Ordinariamente, perjudicar sólo implica ocasionar un daño o detrimento que puede ser material o moral. Esta idea es la que hemos visto primar en la doctrina hasta los años cincuenta aproximadamente ${ }^{78}$, al igual que en la práctica. Así, era usual estimar la existencia de un concurso medial de delitos cuando existía falsificación y perjuicio patrimonial ${ }^{79}$. Es probable que la actual definición patrimonial provenga de la tesis de Carrara por la época de semejante desarrollo ${ }^{80}$.

\footnotetext{
${ }^{78}$ Se mantiene incluso en la actualización de ciertas tesis. Así, además de las tesis de Bañados, Cousiño, Valdés Matus, Ortiz, y antes Fernández, destaca la de Labatut Glena, Derecho..., p. 59 y Garrido Montt, Derecho..., pp. 87 y 89, que parten de una noción patrimonial y luego admiten que el perjuicio no tiene necesariamente esta calidad.

${ }^{79}$ SCS de 15 de marzo de 1919 (Gaceta de los Tribunales, Noviembre i Diciembre, 1918, pp. 142-144); SCS de 14 de enero de 1920 (Gaceta de los Tribunales, Primer Semestre, 1920, pp. 253-262); SCS de 12 de abril de 1928 (Gaceta de los Tribunales, Primer Semestre, 1928, pp. 454-457); SCS de 18 de abril de 1929 (Gaceta de los Tribunales, Primer Semestre, 1929, pp. 316-320); SCS de 30 de diciembre de 1929 (Gaceta de los Tribunales, Segundo Semestre, 1929, pp. 307-311; SCS de 13 de agosto de 1934 (Gaceta de los Tribunales, Segundo Semestre, 1934, pp. 217-220).

${ }^{80}$ Carrara, F., Programa de Derecho criminal: Parte especial, traducido por Ortega Torres, José J., Temis, Bogotá, 1964, vol. VII, pp. 5, 6, 269 concibe esta falsificación "privada" como un delito contra la propiedad y se adhiere a las tesis de Carmignani y Guiliani que postulan la inclusión del título de falsedad dentro de los delitos contra la propiedad. Finzi, La estafa..., p. 17 rechaza la conexión que hace este autor con la falsedad precisamente por la clase de afectación y su gravedad: el estelionato alcanzaría al patrimonio ajeno
} 
Para completar estas ideas, es interesante también el recurso sistemático. La palabra “perjuicio” en el ámbito del Derecho civil tiene una connotación de lesión patrimonial, que se ha de indemnizar. Esta noción, sin embargo, no se mantiene en el campo penal, donde las reparaciones son ajenas ${ }^{81}$. Ello sí ocurre en los delitos de apropiación como la estafa y la apropiación indebida, pero no sucede en todo caso. Por ejemplo: la misma falsificación de documentos públicos en la hipótesis de ocultación en perjuicio del Estado (art. $193 \mathrm{~N}^{\circ}$ 8); uno de los supuestos de prevaricación por revelación de secretos, auxilio o consejos en perjuicio de la parte contraria (art. 224 No 6); la revelación de secretos por el abogado o procurador que perjudicara a su cliente (art. 231); la violación de secretos por parte de un empleado público (art. 247); la entrega de menores de diez años por quienes están a cargo de su crianza o educación a instituciones públicas o a cualquier persona sin anuencia de la persona que lo puso a su cargo con perjuicio grave para el menor (art. 356); la propia falsedad del acta o certificado de matrimonio religioso que realice el ministro de culto "con perjuicio de tercero" (art. 388). Particularmente relevante resulta la regulación de la falsificación de instrumento privado en el Código de Procedimiento Penal, coetáneo a las disposiciones penales que establecen el delito, pues no limita la naturaleza del perjuicio. Su art. 154 señala "Si, para la existencia del delito, se requiere que haya perjuicio de tercero, el juez investigará en qué consiste este perjuicio" 82 . No indica que el juez debe únicamente probar su existencia, sino que establece un mandato para indagar precisamente sobre su naturaleza, sin que se deduzca algún límite económico.

¿Podría alcanzar un bien jurídico de cualquier clase? Falta todavía ver qué sucede desde el fin de la norma que castiga estas falsificaciones. Es fundamental la idoneidad de la conducta de falsedad como la expone Ruiz Pulido ${ }^{83}$, y como suele hacerse con el engaño en la estafa: no cualquier alteración o mudamiento de la verdad será suficiente y se conecta con el bien protegido por las normas que sancionan las falsedades ${ }^{84}$, aun

con una connotación privada, distinto de del crimen falsi que afecta la fe pública y que se sanciona con mayor gravedad. Todavía hoy pueden observarse registros expresos de sus ideas en sentencias nacionales. Por ejemplo, la Corte de Apelaciones de Coyhaique de 7 de noviembre de 2006 (Rol: 105-2006) se funda en la relación que ese autor hace de la falsificación de instrumento privado con el estellionato y no con el crimen falsi, a diferencia de la falsedad de documentos públicos.

${ }^{81}$ Ello sin perjuicio de algunas reglas procedimentales que miran a la víctima, específicamente en las salidas alternativas a la pena, como los acuerdos reparatorios, y de los efectos civiles que procedan de la comisión de un delito (art. 24 del C.P.).

82 Tiene sentido la referencia que de este artículo hace Valdés Matus, De la falsificación..., p. 61, aunque parece remitirse a la prueba de un perjuicio económico, al conectar este elemento con el documento falsificado: exige solo que el perjuicio "sea inherente a la naturaleza probatoria de los hechos de que da fe" tal documento, que derive de su aptitud probatoria (p. 59). Esta declaración se refuerza con la distinción que realiza según la clase de instrumento, donde acepta que la naturaleza económica procede únicamente en los instrumentos privados mercantiles. Para los otros instrumentos privados el perjuicio puede ser también moral (pp. 66-68).

${ }^{83}$ Ver supra nota 28.

${ }^{84}$ Interesante resultan tesis como la de Puppe, I., "§ 267", en NomosKommentar, $3^{\text {a }}$ ed., 2010, t. 2 , pp. 2043, 2044 y 2047 que, sin referirse a un perjuicio (no lo exige la ley alemana) concreta la afectación 
cuando se trate de un instrumento privado. Es una conducta de falsedad y su objeto sí es determinante frente a sus efectos. El menor alcance que ellos suponen -destacado por Pacheco para la ley española que no se limitaba a la producción de perjuicio- importe un menor nivel de injusto que permite justificar todavía la existencia de este perjuicio de tercero. Quizá podría asimilarse la falsificación de documentos públicos y la de instrumentos privados, siempre que se admita que hay un mismo bien jurídico afectado, al tráfico de drogas y al llamado "microtráfico", que alcanzan un único bien protegido (salud pública) y se distinguen en la magnitud de su afectación (un mayor o menor descontrol de la difusión de la droga) precisamente por el objeto traficado. En el caso de instrumentos privados, no se trata de un problema numérico, de cantidad de objetos, sino de alcance o extensión de efectos del documento. Independientemente de esta idea, nuestra ley va más allá de la posible afectación de un bien colectivo, sea cual sea éste ${ }^{85}$, al requerir el citado perjuicio de tercero. Esta exigencia sí implica otro (quien se afecta por la falsedad), un bien individual afectado por la conducta de falsedad idónea y no por un factor diverso. Que ese perjuicio, daño o detrimento sea patrimonial puede al menos cuestionarse cuando esta naturaleza no se deduce de su origen, ni del sentido gramatical, sistemático, ni teleológico de la expresión perjuicio.

de las falsedades en cuanto alcanzan la libre disposición individual y perturban la autonomía privada. Esta idea no se identifica con una lesión patrimonial, aunque sí supone una concreción individual que vincula con la estafa (Betrug). Erb, V., “\$ 267”, en Münchener Kommentar, Beck, München, t. 4, 2006, pp. 590593, pregunta si esto supone la mutación de la falsedad en un delito patrimonial y prefiere el alcance de las funciones del documento. Por supuesto que ello dependerá de la noción de patrimonio que se tenga; si todo es patrimonio, difícil será distinguir algo de él. La perturbación de la autonomía privada por un documento falso no coincide con un daño patrimonial, que sí puede estar en su base (como en la base de todo delito). En general, la tesis de Puppe, como la de Hoyer, es criticada por una concreción que no calza con los términos del StGB alemán que alude en general a la finalidad de afectar la seguridad del tráfico jurídico ("Wer zur Täuschung im Rechtsverkehr”) y que no abarcaría todos los supuestos. Así, Cramer / Heine, "§ $267 ” . . .$, p. 2502.

${ }^{85}$ Puede observarse que quienes se ocupan por definir un bien propio para las falsedades admiten que el perjuicio de tercero puede tener cualquier naturaleza. Así, Cousiño MacIver, La falsificación..., pp. 11, 18, 31-33, 39, 46. Valdés Matus, De la falsificación..., p. 25; Labatut Glena, Derecho..., p. 59. Algo similar podría afirmarse de la Bullemore, V; Mackinnon, J., Curso de Derecho penal. Parte especial II, LegalPublishing, Santiago, 2007, vol. 4, pp. 131 y 132., que habla de una "fe privada" como un derecho a no ser víctima de engaño y busca su concreción en una obligación de decir verdad. Esta idea se encamina a la definición de un bien particular (similar a la tesis Jakobs). Sin embargo, acota que sólo existe obligación de decir verdad en documentos de carácter patrimonial, con lo cual su concreción se pierde en el patrimonio como bien afectado. Más interesante resulta la tesis de Ortiz, "La falsificación...", p. 208, pues sostiene que la fe pública es el bien que se perturba en toda falsedad y por eso no sólo estima el perjuicio como una condición de punibilidad sino que también admite que puede tener una naturaleza distinta de la lesión patrimonial. Por otro lado, autores que aluden a un bien colectivo para el caso de las falsedades de documentos públicos, como la seguridad en el tráfico jurídico, concretan la lesividad de la falsificación de instrumentos privados en la lesión patrimonial que representaría el perjuicio de tercero. Por ejemplo, Etcheberry, Derecho..., t. IV, p. 158; Politoff; Matus; Ramírez, Lecciones..., pp. 451, 556, 570. 


\section{BIBLIOGRAFÍA}

Bacigalupo Zapater, E., "Documentos electrónicos y delitos de falsedad documental", en Revista Electrónica de Ciencia Penal y Criminología, 04-12, 2002, 17 p.

Balmaceda Hoyos, G.; Araya Paredes, I., "Engaño en la estafa: ¿una puesta en escena”, en Revista Estudios Socio-Jurídicos, 2009, 11, (2), pp. 13-45.

Bañados Espinosa, F., Código Penal de la República de Chile concordado y comentado, Dirección de Impresiones L. A. Lagunas M., Santiago, 1920.

Barrientos Zamorano, M., Daños y deberes en las tratativas preliminares de un contrato, LegalPublishing, Santiago, 2008.

Bullemore, V.; Mackinnon, J., Curso de Derecho penal. Parte especial II, LegalPublishing, Santiago, 2007, vol. 4.

Calle Rodríguez, M. V., La falsedad documental inocua en la jurisprudencia española, Universidad Complutense de Madrid, Madrid, 1995.

Carrara, F., Programa de Derecho criminal: Parte especial, traducido por Ortega Torres, José J., Temis, Bogotá, 1964, vol. VII.

Cousiño Mac Iver, L., La falsificación de instrumento privado (ensayo de construcción jurídica del delito en Chile), Stanley, Santiago, 1944 (también en Revista de Ciencias Penales, T. VII, N², 1944, pp. 5-23 y 99-131).

Climent Durán, C., Código Penal con jurisprudencia sistematizada, $4^{\mathrm{a}}$ ed., Tirant lo Blanch, Valencia, 2011.

Cramer / Heine, "§ 267”, en Schönke / Schröder, Strafgesetzbuch Kommentar, 28ª ed., Beck, München, 2010.

Del Río, R., Derecho penal, Nascimento, Santiago, vol. 3, 1935.

ERB, V., “\$ 267”, en Münchener Kommentar, Beck, München, t. 4, 2006.

Etcheberry, A., Derecho penal. Parte especial, $3^{a}$ ed., Editorial Jurídica de Chile, Santiago, 1998, t. III.

Etcheberry, A., Derecho penal. Parte especial, $3^{a}$ ed., Editorial Jurídica de Chile, Santiago, 1998, t. IV.

Etcheberry, A., "El objeto jurídico en los delitos de falsedad documental", en Revista de Ciencias Penales, 1961, t. XX, pp. 33-66.

Etcheberry, A., "El objeto material del delito de falsedad documental: documentos y sus clases", en Revista de Ciencias Penales, 1961, t. XX, pp. 219-240.

Fernández, P. J., Código Penal de la República de Chile esplicado y concordado, $2^{\mathrm{a}}$ ed., Imprenta Litografía y Encuadernación Barcelona, Santiago, 1899.

Garrido Montt, M., Derecho penal, parte especial, $4^{a}$ ed., Editorial Jurídica de Chile, Santiago, 2008, t. IV.

Garrido Montt, M., "El documento, en especial el público o auténtico, en el ámbito penal", en Revista de Derecho, Pontificia Universidad Católica de Valparaíso, t. XXVI, 2005, pp. 195-200.

Feuerbach, P. J. A. R. von, Tratado de Derecho penal, traducción de la $14^{a}$ ed. alemana por Zaffaroni, Eugenio Raúl; Hagemeier, Irma, Hammurabi, Buenos Aires, 1989.

FinZI, C. A., La estafa y otros fraudes, Depalma, Buenos Aires, 1961.

Gómez Benítez, J. M., "Función y contenido del error en el tipo de estafa”, en Anuario de Derecho Penal y Ciencias Penales, t. XXXVIII, Fascículo I, 1985, pp. 333-345.

Groizard y Gómez de la Serna, A., El Código Penal de 1870 concordado y comentado, Imprenta de D. Timoteo Arnaiz, Burgos, t. III, 1874.

Hernández Basualto, H., "La estafa triangular en el derecho penal chileno, en especial la estafa procesal”, en Revista de Derecho, t. XXIII, N 1, 2010, pp. 201-231. 
Hernández Basualto, H., "Uso indebido de tarjetas falsificadas o sustraídas y de sus claves", en Polit. crim., $\mathrm{N}^{\circ}$ 5, 2008, A2-5, pp. 1-38.

Hernández Basualto, H., "Normativización del engaño y nivel de protección de la víctima en la estafa: lo que dice y no dice la dogmática”, en Revista Chilena de Derecho, vol. 37, $\mathrm{N}^{\circ} 1$, 2010, pp. 9-41.

Hirsch, H. J., "Peligro y peligrosidad", traducido por E. Sola Reche, en Anuario de Derecho Penal y Ciencias Penales, vol. XLIX, fasc. II, 1996, pp. 509-528.

Irureta Goyena, J., Falsificaciones documentarias, Imp. Sarandi, S.L., 1958.

Kindhäuser, U., La estafa como autoría mediata tipificada, traducido por Perdomo Torres, J. F., Universidad de Externado de Colombia, Bogotá, 2002.

Jakoвs, G., Falsedad documental. Revisión de un delito de engaño, traducido por López Barja de Quiroga, J.; Rey Sanfiz, L. C., Marcial Pons, Madrid, 2011.

Labatut Glena, G., Derecho penal, $7^{\mathrm{a}}$ ed., actualizada por Zenteno Vargas, J., Editorial Jurídica de Chile, Santiago, 2005, t. II.

Mir Puig, S., "Significado y alcance de la imputación objetiva en Derecho penal", en AA.VV., Modernas tendencias en la ciencia del Derecho penal y en la criminología, Universidad Nacional de Educación a Distancia, Madrid, 2001, pp. 389-408.

Ortiz, P., "La falsificación de instrumento privado (ensayo de construcción jurídica del delito en Chile)", en Revista de Ciencias Penales, t. VII, N. ${ }^{\circ}$ 3, 1944, pp. 207-214.

Pacheco, J. F., El Código Penal concordado y anotado, $5^{\mathrm{a}}$ ed., Imprenta y Fundición de Manuel Tello, Madrid, 1881, t. II.

PIÑa Rochefort, J. I., Fraude de seguros. Cuestiones penales y de técnica legislativa, Editorial Jurídica de Chile, Santiago, 2006.

Politoff, S.; Matus, J. P.; Ramírez, M. C., Lecciones de Derecho penal chileno, parte especial, 2a ed., Editorial Jurídica de Chile, Santiago, 2006.

Politoff Lifschitz, S., “'Cometer' y 'hacer cometer': Desarrollo y significación actual de la noción de autoría mediata”, en Nieto Martín, A. (coord.), Homenaje al Dr. Marino Barbero Santos in memoriam, Ediciones Universidad Castilla-La Mancha, Universidad de Salamanca, Cuenca, 2001, pp. 1231-1284.

Puppe, I., "§ 267”, en NomosKommentar, $3^{a}$ ed., 2010, t. 2.

Rodríguez Collao, L.; Vera Vega, J., "El bien jurídico protegido en los delitos de falsedad", en Revista Escuela de Derecho, Año 5, Número 5, 2004, pp. 109-135.

Ruiz Pulido, G., "Una sentencia insólita”, en Revista de Derecho, Consejo de Defensa del Estado, $\mathrm{N}^{\circ} 2,2000,6$ p. (pp. 422). http://www.cde.cl/wps/wcm/connect/ccfe12004fbf62f1aef8af46ce4e7365/22.pdf?MOD=AJPERES

Ruiz Pulido, G., "Instrumento público y ley penal”, en Revista de Derecho, Consejo de Defensa del Estado, $\mathrm{N}^{\circ}$ 6, 2002, pp. 59-90.

Silva Silva, H., Manual de Derecho penal. Delitos especiales, Thomson Reuters, Santiago, 2010.

Valdés Matus, O., De la falsificación de la letra de cambio, Memoria de Prueba para optar al Grado de Licenciado en Ciencias Jurídicas y Sociales de la Universidad de Chile, Editorial Universitaria, Santiago, 1960.

Vera, R., Código Penal de la República de Chile comentado, Imprenta de P. Cadot y Ca, Santiago, 1883.

Zuloaga Ríos, I. M., Teoría de la responsabilidad precontractual. Aplicaciones en la formación del consentimiento en los contratos, LegalPublishing, $3^{\mathrm{a}}$ ed., Santiago, 2008. 